\section{The Importance of Echocardiography in Detecting Coronary Artery Anomalies in Children}

\author{
Çocuklarda Koroner Arter Anomalilerini Tespit \\ Etmede Ekokardiyografinin Önemi
}

Tulay Demircan $\odot$ Baris Guven $\odot$

Cem Karadeniz $\odot$

Ali Rahmi Bakiler $\odot$

Dilek Oncel $\odot$ Nazmi Narin $\odot$

\section{ABSTRACT}

Objective: There is no established current algorithm of treatment and clinical follow-up in children with coronary artery anomalies. We analysed the clinical characteristics, diagnosis treatment options of children and adolescents identified with coronary artery anomalies

Method: In this retrospective study, 4000 children who attended to our clinic were included between January 2016 and January 2018 at paediatric cardiology department. We reviewed the medical records of 12 patients who had suspicion of coronary-artery anomalies by transthoracic echocardiography.

Results: Twelve cases were detected to have coronary artery anomalies. All patients were childrenadolescent with a mean age at the time of diagnosis of $10.7 \pm 5$ years. None of the patients had cardiac ischemia symptoms. Most common anomaly (5 patients) was the left circumflex coronary artery $(\mathrm{Cx})$ originating from the right coronary artery (RCA). Surgical therapy is recommended in two of 12 patients with interarterial course of coronary artery anomaly.

Conclusion: Echocardiography is an important diagnostic tool in childhood due to acoustic window quality. It is crucial to identify children, particularly children with anomalous origin of coronary arteries who will participate competitive sports. Additional imaging tools including computer tomography angiography, magnetic resonance angiography and coronary angiography are needed to confirm the definite diagnosis.

Keywords: echocardiography, coronary, children, anomalies, congenital

\section{öz}

Amaç: Koroner arter anomalisi olan çocuklarda güncel bir tedavi ve klinik izlem algoritması mevcut değildir. Çalışmamızda çocuklarda ve adölesanlarda koroner arter anomalilerinin klinik özellikleri, tanı ve tedavi seçenekleri analiz edildi.

Yöntem: Bu retrospektif çalışmaya Ocak 2016-Ocak 2018 tarihleri arasında pediyatrik kardiyoloji kliniğimize gelen 4000 çocuk hasta alındı. Transtorasik ekokardiyografi ile koroner arter anomalisi düşünülen 12 olgunun medikal kayıtları retrospektif olarak incelendi.

Bulgular: On iki olguda koroner arter anomalisi olduğu tespit edildi. Tüm hastalar çocuk ve ergen olup, ortalama tanı yaşı 10,7 \pm 5 yıl idi. Hastaların hicbirisinde kardiyak iskemi semptomları yoktu. En yaygın anomali (5 hasta), sağ koroner arterden (RCA) kaynaklanan sol sirkumfleks koroner arter (CX) idi. On iki hastadan koroner arteri interarteriyel seyirli olan iki olguya cerrahi tedavi önerildi.

Sonuç: Ekokardiyografi, akustik pencere kalitesi nedeniyle çocukluk çağında önemli bir tanı aracıdır. Özellikle yarışmalı sporlara katılacak çocuklarda anormal kökenli koroner arterleri belirlemek çok önemlidir. Kesin tanıyı doğrulamak için bilgisayarlı tomografi anjiyografi, manyetik rezonans anjiyografi ve koroner anjiyografi gibi ek görüntüleme yöntemlerine ihtiyaç vardır.

Anahtar kelimeler: ekokardiyografi, koroner, çocuk, anomali, konjenital
Alındığı tarih: 24.09 .2019

Kabul tarihi: 19.12.2019

Online Yayın tarihi: 30.03 .2020

Tulay Demircan Tepecik Training and Research Hospital, Department of Pediatric Cardiology, Izmir, Turkey

tulay.sirin@hotmail.com ORCID: 0000-0002-2529-2906

B. Guven 0000-0002-4520-5574 A.R. Bakiler 0000-0001-8234-3071

Tepecik Training and Research Hospital, Department of Pediatric Cardiology, Izmir, Turkey

C. Karadeniz 0000-0003-0529-2391 N. Narin 0000-0003-2713-364X Katip Celebi University, School of Medicine, Department of Pediatric Cardiology, Izmir, Turkey

D. Oncel 0000-0001-5341-5558 Tepecik Training and Research Hospital, Department of Radiology, Izmir, Turkey 


\section{INTRODUCTION}

Congenital coronary anomalies (CAAs) are uncommon clinical conditions with the incidence of 1-5\% based on coronary angiographic studies ${ }^{(1-3)}$. In autopsy-based surveys of the population of young athletes with sudden cardiac death, coronary anomalies were found to be in up to $14 \%$ of the cases ${ }^{(4)}$. Although angiography plays an important role in the diagnosis, imaging modalities including computed tomography (CT), magnetic resonance imaging (MRI) and intravascular ultrasonography were crucial in the assessment of patients with coronary artery anomalies and, in planning the therapeutic options. There have been several reports documenting identification of these anomalies by transthoracic echocardiography ${ }^{(5-7)}$. Nevertheless, operator dependency and patients with the limited acoustic window may limit the use of transthoracic echocardiography (TTE). In this report, we aimed to describe a singlecentre experience with children and adolescents having coronary-anomalies, and to identify the clinical characteristics, diagnosis and treatment options.

\section{MATERIAL and METHODS}

\section{Study design}

This was a retrospective single-center study based on data concerning the period between January 2016 and January 2018. This retrospective study was approved by the institutional ethics committee of our hospital. (2018/10-9) All procedures performed were in accordance with the 1964 Helsinki declaration.

\section{Patients}

Twelve patients were recruited from a total of 4000 patients with congenital heart disease. We reviewed the medical records of 12 patients who had a suspect coronary-artery anomalies by TTE. Data concerning age, gender, symptoms at admission, associated diseases and family history were recorded. All patients underwent electrocardiography, echocardiography and treadmill test.

\section{Echocardigraphic examination and CT angiography}

The same paediatric cardiology specialist performed the echocardiographic examination by using Philips Ultrasound System and an S 3-1 probe. TTE protocol includes the following two-dimensional views obtained with colour, pulse, and continuous Doppler USG where indicated as subcostal coronal and sagittal, apical four and five chamber, parasternal long, parasternal short, and suprasternalviews. Since echocardiography is not sufficient to reveal the course of the coronary artery, coronary CT angiography and conventional angiography were performed for definitive diagnosis. Oral beta blocker (Metoprolol) was started before the procedure of coronary $\mathrm{CT}$ angiography.

\section{RESULTS}

Of these 4000 patients, twelve cases were detected to have coronary artery anomalies. TTE was false positive in three patients. All patients were children, and adolescents with a mean age of $10.7 \pm 5$ years at the time of diagnosis. Five female, and seven male patients were included in the study. None of the patients had symptoms of cardiac ischemia. Four patients had nonspecific chest pain. Four cases were admitted to our clinic due to pre-participation screening. One patient had palpitations. Two patients had patent ductus arteriosus, and one patient had a diagnosis of tetralogy of Fallot. Coronary CT angiography was performed in 10, coronary angiography in 6 and myocardial perfusion scintigraphy in 4 patients. The primary diagnosis was established in three patients with conventional angiography and coronary CT angiography was needed in 9 patients for confirmation of the diagnosis. Eight patients had the anomalous origin of coronary arteries stemmed from the opposite sinus. Five patients had left circumflex coronary artery $(\mathrm{Cx})$ originating from the right coronary artery (RCA). Three patients had left coronary arteries (LMCA) originating from RCA. Among patients who had anomalous origin stemming from a right coronary artery, two patients had LMCA with anomalous interarterial course between the aorta and the pulmonary artery (Figures 1 , and 2), the 

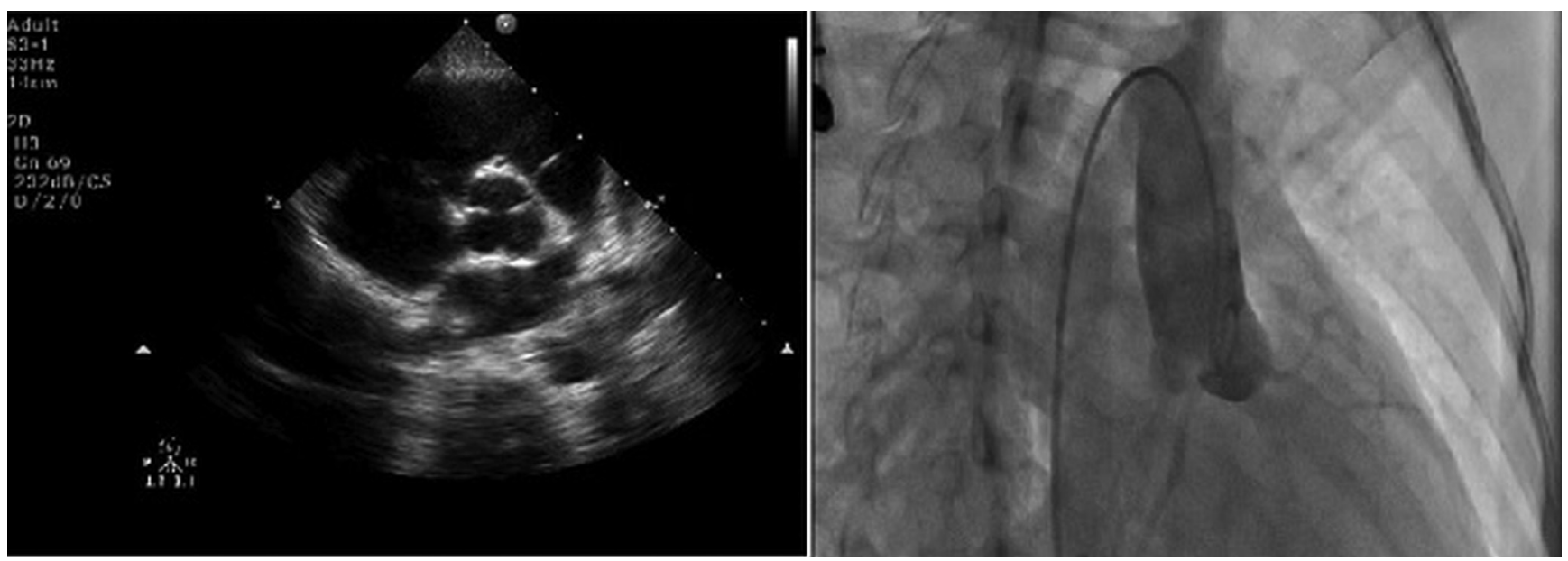

Figure 1. a: Transthoracic echocardiography (TTE) parasternal short axis views and b: coronary angiography of shows the origin of the LMCA arising from the right sinus of Valsalva LMCA: left main coronary artery (Case 2).

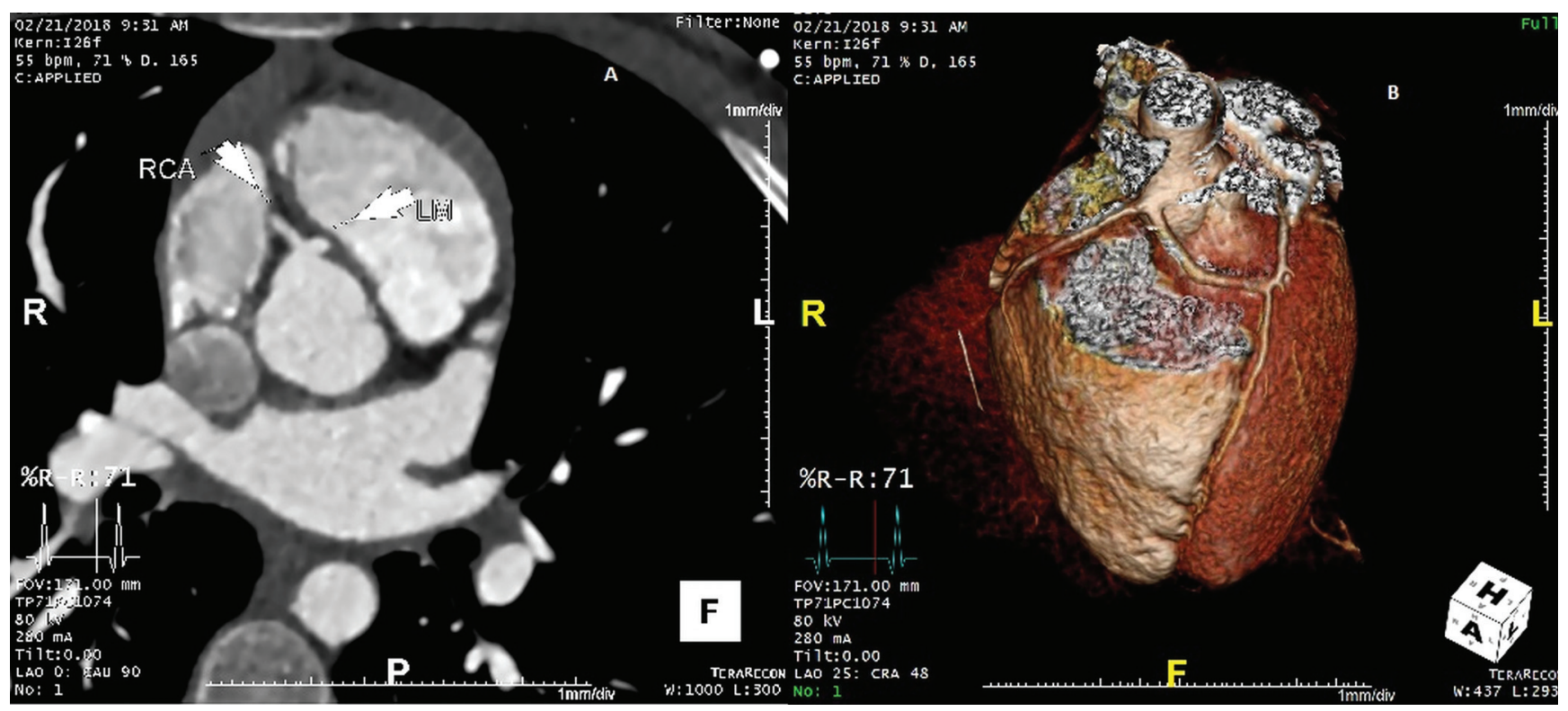

Figure 2. a-b: Coranary CT angiography. Origin of the LM from the right sinus of valsalva is shown. LM: left main coronary artery, RCA: Right coronary artery (Case 10).

remaining patient had LMCA which coursed posteriorly to the aorta as its usual course. Three patients had myocardial bridging. One patient had a coronary arteriovenous fistula. The exercise test was performed as a diagnostic tool in eight patients. Among these, one patient had deep $Q$ waves in all derivations throughout the test. Myocardial bridging in left anterior descending coronary artery was detected in $\mathrm{CT}$ angiography in this patient. Myocardial bridging was located in the mid-LAD in one patient and located in the right coronary artery in another patient.
Surgical therapy is recommended in two of 12 patients with interarterial course of coronary artery anomaly. The characteristics of children are presented in Table 1.

\section{DISCUSSION}

Coronary artery anomalies (CAAs), which occur in isolated form or in association with congenital heart diseases, are now diagnosed with increasing frequency due to improvement in imaging modalities and 
Table 1. Cor onary artery anomalies cases data.

\begin{tabular}{|c|c|c|c|c|c|c|c|}
\hline Case & $\begin{array}{l}\text { Years/ } \\
\text { Sex }\end{array}$ & $\begin{array}{l}\text { Causes of hospital } \\
\text { admission }\end{array}$ & $\begin{array}{l}\text { Coronary } \\
\text { anomaly }\end{array}$ & $\begin{array}{l}\text { Diagnostic } \\
\text { modality }\end{array}$ & $\begin{array}{l}\text { Exercise } \\
\text { test }\end{array}$ & MPS & Decision \\
\hline 1 & $12 / \mathrm{M}$ & None-sport screening & Myocardial bridging in the RCA & CT angiography & Negative & Normal & $\begin{array}{l}\text { Restricted from all } \\
\text { competitive sports }\end{array}$ \\
\hline 2 & $17 / F$ & Father exitus (SCD) & $\begin{array}{l}\text { LMCA from the right } \\
\text { sinus of valsalva and shows } \\
\text { an interarterial course } \\
\text { between the aorta and PA }\end{array}$ & CT angiography & Negative & - & Surgical correction \\
\hline 3 & $14 / F$ & None-sport screening & $\mathrm{LCX}$ originating from the RCA & CT angiography & - & - & Follow-up \\
\hline 4 & $1 / F$ & Tetralogy of Fallot & $\mathrm{LCX}$ originating from the RCA & Angiography & - & - & Follow-up \\
\hline 5 & $8 / F$ & PDA closure & LMCA originating from the RCA & Angiography & Negative & Normal & $\begin{array}{l}\text { Restricted from all } \\
\text { competitive sports }\end{array}$ \\
\hline 6 & $3 / \mathrm{M}$ & PDA closure & LCX originating from the RCA & Angiography & - & - & Follow-up \\
\hline 7 & $11 / \mathrm{M}$ & Sport screening & Myocardial bridges of the LAD & CT angiography & Positive & Normal & $\begin{array}{l}\text { Restricted from all } \\
\text { competitive sports }\end{array}$ \\
\hline 8 & $13 / \mathrm{M}$ & Nonspecific chest pain & CCF (LAD-PA) & CT angiography & Negative & - & $\begin{array}{l}\text { Restricted from all } \\
\text { competitive sports }\end{array}$ \\
\hline 9 & $15 / M$ & Sport screening & LCX originating from the RCA & CT angiography & Negative & - & Follow-up \\
\hline 10 & $12 / \mathrm{M}$ & Chest pain & $\begin{array}{l}\text { LMCA from the right sinus of } \\
\text { valsalva and shows an } \\
\text { interarterial course between } \\
\text { the aorta and PA }\end{array}$ & CT angiography & - & - & Surgical correction \\
\hline 11 & $7 / \mathrm{M}$ & Sport screening & LCX originating from the RCA & CT angiography & Negative & - & Follow-up \\
\hline 12 & $16 / F$ & Arrhythmia, DM & Myocardial bridges in the LAD & CT angiography & Negative & $\begin{array}{c}\text { Findings of } \\
<10 \% \text { ischemia }\end{array}$ & $\begin{array}{l}\text { Restricted from all } \\
\text { competitive sports }\end{array}$ \\
\hline
\end{tabular}

LMCA: Left main coronary artery; LAD: Left anterior descending; LCx: left circumflexcoronary arteries; RCA: Right coronary artery; CCF: Coronary cameral fistula; RV: Right ventricle; PA: pulmonary artery; MPS: Myocardial perfusion scintigraphy; SCD: Sudden cardiac death; DM: Diabetes mellitus; PDA: patent ductus arteriosus.

increased awareness of physicians. The majority of cases are asymptomatic with normal physical examination and ECG findings. Therefore, it is diagnosed most often as an incidental finding, or in autopsies $(4,5)$. Sudden death is frequently the first manifestation, especially the anomalous origin of a coronary artery in young people is related to sportive activities. The prevention of sudden death is only possible with early diagnosis. Although coronary angiography is the gold standard for the diagnosis of CAA, MRI and coronary $\mathrm{CT}$ angiography have been used to document these anomalies ${ }^{(8)}$. In our series, we first used transthoracic echocardiography to diagnose coronary artery anomalies. Coronary CT angiography and angiography were used for definitive diagnosis. TTE is a noninvasive valuable tool for showing coronary artery anomalies in the children and young adolescents, and especially for visualisation of proximal segments of coronary artery. In a study which evaluated the ostium and course of coronary arteries in athletes, TTE showed a good interobserver variability and reliability for showing origins and diameters of coronary arteries ${ }^{(9)}$. Davis et al. ${ }^{(10)}$ studied 2388 cases who had not structural heart diseases, and they identified four cases with coronary arteries originating from contralateral sinus by transthoracic 
echocardiography. In our series, 3 patients (25\%) had LMCA originating from contralateral sinus.

However, TTE is not feasible for visualization of the anomalous course of coronary artery. Additional imaging tools, such as CT angiography and conventional angiography are needed to confirm diagnosis of anomalous origin and the course of coronary arteries. Schmitt et al. ${ }^{(11)}$ reviewed 1758 subjects who underwent cardiac CT, they found 44 cases with coronary artery anomalies. Twenty of these 44 cases underwent coronary angiography, and only 11 coronary anomalies were confirmed. In 2008 ACC/AHA guideline, coronary $\mathrm{CT}$ and MR angiography along with coronary angiography have been recommended as class IA in visualisation of coronary artery anomalies originating from contralateral coronary sinus. Intravascular ultrasonography has been recommended in several reports ${ }^{(12-14)}$.

The autopsy series revealed that left main coronary artery originating from contralateral sinus was found in $0.17 \%$, and with an incidence of $1.2 \%$ in angiographic studies ${ }^{(2,3,15)}$. Although the majority of cases are asymptomatic, sudden death related to sportive or non-supportive activities has been described in $30 \%$ of the cases with this anomaly ${ }^{(16)}$. Previous reports suggested that AOCA of either coronary artery carries a significant risk of sudden death, especially in young athletes. In our report, most common coronary anomaly is left circumflex coronary artery originating from RCA which was also documented as the most common anomaly in angiography series ${ }^{(17)}$. Although usually benign, angina pectoris, myocardial ischemia, syncope and arrhythmias have been reported rarely. Identification of this anomaly is crucial to avoid the risk of myocardial infarction during the mitral valve surgery. Angelini et al. ${ }^{(18)}$ studied 1836 healthy school children using MR angiography. In 13 cases with coronary anomalies, 11 had RCA originating from left sinus and 2 had LMCA originating from contralateral sinus.

Another common abnormality in our series was myocardial bridging (MB) which is defined as a segment of an epicardial coronary artery with an intramyocardial course ${ }^{(19,20)}$. MB is generally located in the mid segment of the left anterior descending artery.

Our study had some limitations that to be considered. First, relatively small sample size was the foremost limitation of our study. Second, we could not evaluate the long-term follow-up results of our patients.

There are limited data in children with coronary artery anomalies. Coronary artery anomalies can pose a serious concern for morbidity and mortality in children and adolescents. The diagnosis can be challenging in children. In this report, we showed that TTE is a valuable tool for the diagnosis of coronary arteries. However, more studies with larger populations might increase the power of our study.

In conclusion, TTE is an important tool in detecting coronary artery anomalies. But, TTE is insufficient for delineating the course of coronary arteries.

Currently, computed tomography angiography is considered gold standard for demonstrating the coronary anatomy. CT angiography shows not only the origin of the coronary arteries but also their course and relationships with other mediastinal structures. Therefore CT angiography should be requested from patients with family history, cardiac complaints and suspected coronary artery anomalies detected by TTE.

Ethics Committee Approval: Ethics committee approval was received from Tepecik Training and Research Hospital on 08/08/2018 and numbered 2018/10-9.

Conflict of Interest: There is no conflict of interest related to the author or study findings.

Funding: Not available. Informed Consent was obtained from all patients for autopsy.

Informed Consent: Informed consent was received from all patients.

\section{REFERENCES}

1. Frommelt PC, Frommelt MA. Congenital coronary artery anomalies. Pediatr Clin North Am. 2004;51:1273-88. https://doi.org/10.1016/j.pcl.2004.04.014

2. Yamanaka O, Hobbs RE. Coronary artery anomalies in 126,595 patients undergoing coronary arteriography. Cathet Cardiovasc Diagn. 1990;21:28-40. https://doi.org/10.1002/ccd.1810210110

3. Solanki P, Gerula C, Randhawa P, Benz M, Maher J, Haider B et al. Right coronary artery anatomical variants: where and 
how? J Invasive Cardiol. 2010;22:103-6.

4. Maron BJ. Sudden death in young athletes. N Engl J Med. 2003;349:1064-75.

https://doi.org/10.1056/NEJMra022783

5. Frommelt PC, Berger S, Pelech AN, Bergstrom S., Williamson J.G. Prospective identification of anomalous origin of left coronary artery from the right sinus of Valsalva using transthoracic echocardiography: importance of color Doppler flow mapping. Pediatr Cardiol. 2001;22:327-32. https://doi.org/10.1007/s002460010239

6. Labombarda F, Coutance G, Pellissier A, Alexandre CM, Roule $\mathrm{V}$, Maragnes $\mathrm{P}$ et al. Major congenital coronary artery anomalies in a paediatric and adult population: a prospective echocardiographicn study. Eur Heart J Cardiovasc Imaging. 2014;15: 761-768. https://doi.org/10.1093/ehjci/jet287

7. Zeppilli P, Dello Russo A, Santini C, Palmieri V, Natale L, Giordano A et al. In vivo detection of coronary artery anomalies in asymptomatic athletes by echocardiographic screening. Chest. 1998;114:89-93. https://doi.org/10.1378/chest.114.1.89

8. Brothers JA,Whitehead K, Keller MS, Fogel MA, Paridon SM, Weinberg PM et al. Cardiac MRI and CT: differentiation of normal ostium and intraseptal course from slit-like ostium and interarterial course in anomalous left coronary artery in children. AJR Am. J. Roentgenol. 2015;204:104-9. https://doi.org/10.2214/AJR.14.12953

9. Hoyt WJ, Dean PN, Schneider DS, Conaway MR, Kramer CM, Battle RW. Coronary artery evaluation by screening echocardiogram in intercollegiate athletes. Medicine and Science in Sports and Exercise. 2017;49:863-9. https://doi.org/10.1249/MSS.0000000000001182

10. Davis JA, Cecchin F, Jones TK, Portman MA. Major coronary artery anomalies in a pediatric population: incidence and clinical importance. J Am Coll Cardiol. 2001;37:593-7. https://doi.org/10.1016/S0735-1097(00)01136-0

11. Schmitt R, Froehner S, Brunn J, Wagner $M$, Brunner $H$, Cherevatyy $\mathrm{O}$, et al. Congenital anomalies of the coronary arteries: imaging with contrast-enhanced, multidetector computed tomography. Eur Radiol. 2005;15:1110-21. https://doi.org/10.1007/s00330-005-2707-z

12. Warnes CA, Williams RG, Bashore TM, Child JS, Connolly HM, Dearani JA et al. ACC/AHA 2008 Guidelines for the Management of Adults with Congenital Heart Disease: a report of the American College of Cardiology/American
Heart Association Task Force on Practice Guidelines (writing committee to develop guidelines on the management of adults with congenital heart disease). Circulation. 2008;118:714-833.

https://doi.org/10.1161/CIRCULATIONAHA.108.190811

13. Angelini $P$. Novel imaging of coronary artery anomalies to assess their prevalence, the causes of clinical symptoms, and the risk of sudden cardiac death. Circ Cardiovasc Imaging. 2014;7:747-54. https://doi.org/10.1161/CIRCIMAGING.113.000278

14. Van Hare GF, Ackerman MJ, Evangelista JA, Kovacs RJ, Myerburg RJ, Shafer KM et al. Eligibility and disqualification recommendations for competitive athletes with cardiovascular abnormalities: task force 4: congenital heart disease: a scientific statement from the American Heart Association and American College of Cardiology. J Am Coll Cardiol. 2015;66:2372-84. https://doi.org/10.1016/j.jacc.2015.09.036

15. Krasuski RA, Magyar D, Hart S, Kalahasti V, Lorber R. Longterm outcome and impact of surgery on adults with coronary arteries originating from the opposite coronary cusp. Circulation. 2011;123(2):154-62. https://doi.org/10.1161/CIRCULATIONAHA.109.921106

16. Taylor AJ, Rogan KM, Virmani R. Sudden cardiac death associated with isolated congenital coronary artery anomalies. J Am Coli Cardiol. 1992;20:640-7. https://doi.org/10.1016/0735-1097(92)90019-J

17. Safi AM, Rachko M, Tang A, Ketosugbo A, Kwan T, Afflu E. Anomalous origin of the left main coronary artery from the right sinus of Valsalva: disabling angina and syncope with noninterarterial courses case report of two patients. Heart Dis. 2001;3:24-7.

18. Angelini P, Shah NR, Uribe CE, Cheong B, Lopez V, Lenge V et al. Novel MRI based screening protocol to identify adolescents at high risk of sudden cardiac death. Presented at the 62 Annual Scientific Session Expo; 2013 March; San Francisco. American College of Cardiology Foundation. 2013;61:1621. https://doi.org/10.1016/S0735-1097(13)61621-6

19. Alegria JR, Herrmann J, Holmes DR, Lerman A, Rihal CS. Myocardial bridging. Eur Heart J. 2005;26:1159-68. https://doi.org/10.1093/eurheartj/ehi203

20. Angelni P, Velasco JA, Flamm S. Coronary anomalies: incidence, pathophysiology, and clinical relevance. Circulation. 2002;105:2449-54. https://doi.org/10.1161/01.CIR.0000016175.49835.57 